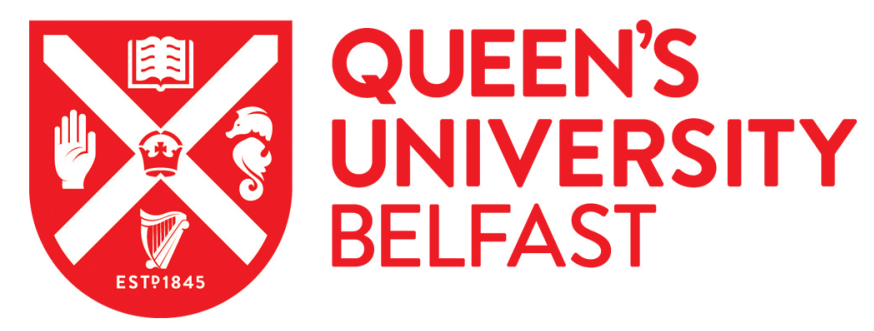

\title{
Value capture: a valid means of funding PPPs?
}

Connolly, C., \& Wall, A. (2016). Value capture: a valid means of funding PPPs? Financial Accountability \& Management, 32(2), 157-178. https://doi.org/10.1111/faam.12083

\author{
Published in: \\ Financial Accountability \& Management
}

\section{Document Version:}

Peer reviewed version

\section{Queen's University Belfast - Research Portal:}

Link to publication record in Queen's University Belfast Research Portal

\section{Publisher rights}

(C) 2016 John Wiley \& Sons Ltd.

This is the peer reviewed version of this article which has been published in final form at doi:10.1111/faam.12083. This article may be used for non-commercial purposes in accordance with Wiley Terms and Conditions for Self-Archiving.

\section{General rights}

Copyright for the publications made accessible via the Queen's University Belfast Research Portal is retained by the author(s) and / or other copyright owners and it is a condition of accessing these publications that users recognise and abide by the legal requirements associated with these rights.

Take down policy

The Research Portal is Queen's institutional repository that provides access to Queen's research output. Every effort has been made to ensure that content in the Research Portal does not infringe any person's rights, or applicable UK laws. If you discover content in the Research Portal that you believe breaches copyright or violates any law, please contact openaccess@qub.ac.uk. 
Value Capture: A Valid Means of Funding PPPs?

\author{
Ciaran Connolly \\ Queen's University Belfast
}

and

Tony Wall

University of Ulster

Please address all correspondence to:

Ciaran Connolly

Queen’s University Management School

Queen’s University Belfast

185 Stranmillis Road

Belfast

BT9 5EE

Northern Ireland

Tel: +44 (0)2890974796

E-mail: c.j.connolly@qub.ac.uk 


\title{
Value Capture: A Valid Means of Funding PPPs?
}

\begin{abstract}
This paper considers the use of value capture (VC) as a means of financing publicprivate partnerships (PPPs) in the United Kingdom (UK). Although some VC techniques are used in the UK, they are employed more widely in the United States of America. After considering the traditional approach to financing UK PPPs, this paper describes the main VC finance instruments. The findings of a series of case studies are then presented and conclusions drawn. While VC financing may prove unpopular with those bearing the cost of infrastructure improvements, it is recommended that such instruments are considered by UK policy makers.
\end{abstract}

Keywords: value capture, public-private partnerships, infrastructure improvements 


\section{Value Capture: A Valid Means of Funding PPPs?}

\section{INTRODUCTION}

The funding of infrastructure projects has become increasingly complex, particularly in the last two decades. Previously, such projects were typically funded directly by government, with contributions from users either directly or indirectly (e.g., with respect to transit-related projects through fares, fuel taxes and vehicle registration). The issue of who should pay is important, and if the paradigm is that improvements only result in increased user convenience then users should bear the cost. However, the benefits are often wider (e.g., new schools or improved transit links may lead to capital gains accruing to property owners). Moreover, the financing issue is complicated by factors such as environmental impact costs and to what extent these should be borne by future generations.

Recent years have seen greater private sector involvement in the funding of public sector infrastructure projects, together with their design, construction and operation through Private Finance Initiative (PFI)/Public Private Partnership (PPP) contracts. Although there are a variety of arrangements that fall under the PPP umbrella, the most controversial remain those containing PFI characteristics. The use of private money to finance public sector infrastructure, such as schools and hospitals, was deemed to be flawed from the outset as public money was cheaper to borrow. However, the proponents of utilising private funding maintained that efficiencies gained in the construction and operating phases of the contract would compensate for higher interest rates. Moreover, the availability of private finance meant more projects could be undertaken than under conventional procurement; although this latter argument is weakened with the economic recession and the reluctance of banks to lend.

This paper examines value capture (VC), a method employed in the United States of America (USA) which has gained popularity in recent years, particularly with respect to the repayment of transit PPP finance, because it is perceived as being socially equitable since it transfers some of the financial burden to users and others who will benefit from the new or improved infrastructure. In terms of format, the paper begins with an overview of the financing of PPPs. This is followed by a discussion of value creation and VC, including the main VC instruments. After outlining the methodology, four case studies that have employed various VC instruments are presented and discussed. Finally, conclusions are drawn. 


\section{THE FINANCING OF PUBLIC PRIVATE PARTNERSHIPS}

Criticising the use of PPPs, and its forerunner the PFI, has been the focus of many UK studies (e.g., Edwards and Shaoul, 2003; Broadbent et al., 2008; Pollock and Price, 2008). The number and value of UK projects grew steadily until 2007 (Her Majesty’s Treasury (HMT), 2006) when the banking crisis began to impact upon lending. Traditionally, major PPP projects that availed of private finance used a combination of debt and equity with their respective mix typically being $90 \%$ and $10 \%{ }^{1}$. Initially, the debt consisted of bank lending and bonds, the latter being backed by the monoline industry ${ }^{2}$ which guaranteed repayment if an issuer defaulted. However, following the 2007 housing market decline, this industry collapsed resulting in the closure of the wrapped bond market (BBC, 2009). Consequently, the only viable source of finance for infrastructure projects was banks; however the demise of Lehman Brothers in September 2008 meant the global lending market dried up as interbank confidence fell (Connolly and Wall, 2011).

Notwithstanding the aforementioned criticisms, two significant characteristics of PFI may explain its ongoing attractiveness (Gregory and Dawber, 2012). Firstly, while accounting rule changes mean most projects now appear 'on balance sheet' in accounting terms, the liabilities are excluded from calculations of overall public sector net debt and a PFI deal has less immediate impact on a public body's capital budget than a traditionally-procured project. Secondly, while not without its complications, PFI is relatively straightforward, especially following the establishment of contract templates and centres of expertise (nationally and internationally).

The former Labour Government proposed a number of initiatives to try to ensure that viable PPP projects proceeded despite a lack of funding. These included mini-perm ${ }^{3}$ structures (KPMG, 2009) and HMT lending (HMT, 2009). However, only a few PPPs used mini-perms (KPMG, 2009) and only one major PPP was partly financed by HMT (National Audit Office, 2010). When the UK Coalition Government came into power in 2010 it announced major changes to the PPP system and a major capital investment programme using money from both pension funds and overseas, it also stated it would increase the value for money (VFM) obtained from future projects (BBC, 2010, 2011). However, whilst both these sources are not conventional debt they still result in future generations of taxpayers paying for assets from which they may not personally benefit. 
The issue of whether PPPs provide VFM has been a subject of great academic interest. Whilst Heald (2003) saw the potential for VFM from PPP projects, such as the improved management of construction, he also believed it was undermined by an appraisal process that was subject to excessive gaming. Shaoul (2005) also felt that the appraisal process was flawed, leading to a loss of benefits for the wider public, and redistributed income to an elite few, particularly 'financial institutions whose loans are effectively underwritten by the taxpayers' (p. 465). Similar arguments have been posited by Froud and Shaoul (2001) and Broadbent et al. (2003). A more equitable approach would be for those who benefit to share the cost; this is the rationale underpinning VC.

\section{WHAT IS VALUE, HOW IS IT CREATED AND WHO CAPTURES IT?}

Drawing on the resource-based theory of the firm, a resource is considered to be valuable if it: exploits opportunities and/or neutralises threats; allows customer needs to be better satisfied; or enables a firm to satisfy needs at lower costs than competitors (Barney, 1991). When assessing value, it is useful to distinguish between 'use value' and 'exchange value' (Lepak et al., 2007). Use value refers to the specific quality of a new product or service as perceived by users in relation to needs; it is subjective and individual specific. Exchange value refers to the monetary amount realised when the exchange of the new product or service occurs; VC is the realisation of exchange value.

Inanimate resources are incapable of transforming themselves into anything other than what they are and need to be developed before they can contribute to the production of new use values. However, added exchange value may not necessarily be created; this depends upon the relative amount of value that is subjectively realised by a target user. Moreover, this subjective value realisation must translate into the user's willingness to exchange a monetary amount. Two key assumptions underpinning this are: the monetary amount exchanged exceeds the producer's costs of creating the value; and the monetary amount that a user will exchange is a function of the perceived difference between the new value created and the closest alternative.

Value creation requires more than simply understanding what a customer or society is willing to pay, it requires recognising that multiple users exist in concert not isolation (Lepak et al., 2007). Moreover, as the knowledge of potential users and the context in which they make evaluations about newly created value are relevant, how value is captured must be considered. Two key concepts determine which party captures the newly created value: competition and 
isolating mechanisms. As novelty and appropriateness increase so does use and exchange value, leading to limited supply and high demand. Consequently, competition is then likely to ensue, increasing supply and probably leading to a fall in exchange value to where supply equals demand. Therefore, competition can help explain why value slips. However, in some cases, competition is limited and supply does not equal demand, thus offering the potential for greater VC.

An isolating mechanism is any knowledge or physical or legal barrier that prevents replication of the value-creating product or service by a competitor, thus enabling the source of value creation to capture the majority of value created. Barney (1991) argues that resources may serve as isolating mechanisms and limit competition in cases where they are rare, inimitable and non-substitutable. Lepak et al. (2007) suggest that societies with specific resource advantages (e.g., natural resources) can capture more value than those lacking them.

\section{VALUE CAPTURE}

\section{What is Value Capture?}

The presence of facilities/services (e.g., transit) can increase property values and provide development opportunities. In the USA, various studies have examined the impact of new or improved urban railway stations on land use and rents (Smith and Gihring, 2006). In general, these studies have concluded that rail transit significantly benefits land use and rents if a region's economy is growing and a number of supportive programmes are established (e.g., the creation of pedestrian plazas) (Cervero, 1994). Given current funding constraints and demands for new and improved public services, policy makers are increasingly examining ways of harnessing the value that infrastructure improvements confer on surrounding areas to help fund such investments (Gregory and Dawber, 2012). Value capture is a potential means of financing infrastructure investment if some or all of the exchange value added through infrastructure development can be realised (Batt, 2001). This might be value that could generate an immediate benefit for the owner (e.g., a developer selling land near a new road access point at a higher price than could have been obtained beforehand). Alternatively the value may relate to owning a property near new infrastructure that may provide future financial value (e.g., increased property prices) but also immediately if, for example, the owner's journey time is reduced. Therefore the project's costs might at least be partly obtained by taxes or levies imposed on 
those likely to benefit (rather than through user charges), making VC economically neutral as it imposes no distortions on economic choices because strategically-located land is limited in supply and therefore inelastic (Batt, 2001).

Broadly, VC is likely to be appropriate for any new asset that increases land and property values. Improvements in transit increase accessibility to jobs and schools, and easily accessible locations tend to command higher prices. Local authorities may therefore exploit rising property values to encourage transit-oriented development and help fund neighbourhood improvements such as affordable housing. In addition, property owners and developers view transit as a highly desirable amenity with the potential to increase the value of surrounding properties and create development opportunities. The benefits (value added) of living near good public transport are fiscal (e.g., increased property values), social (e.g. neighbourhood revitalisation) and environmental (e.g., reduced traffic congestion) (Center for Transit-Oriented Development (CTOD), 2008).

\section{The Origins of Value Capture}

The concept behind VC, particularly using transit to open up new land for development and thereby increasing its value, is not new. It can be traced back to $19^{\text {th }}$ century French physiocrats ${ }^{4}$ whose approach compares closely to the thinking of Henry George in the $20^{\text {th }}$ century (Batt, 2001). The physiocrats believed that 'land is the unique source of wealth’ (Quesnay, 1963, p. 232) and, living in an age when agriculture was a major economic activity, 'regarded production in terms of the transformation of materials and food taken from the land' (Christensen, 1989, p. 18). George deemed that land was the property of all and that pure rent, that is income received from this resource, was unearned and undeserved. Therefore he believed all taxation should be based on land values. As the returns from land taxes continued to fall throughout the $20^{\text {th }}$ century Georgist ideas were deemed outdated (Andelson, 1979); however the merits of a land-value tax as one amongst many still remain and provide the rationale for VC.

\section{Value Capture Instruments}

The funding mechanisms and finance instruments for public sector infrastructure projects are illustrated in Table 1. Traditional funding mechanisms are general tax revenue and user fees, with the former tending to be applied when the relationship between who pays and who benefits is imprecise and the latter when the relationship is clearer. Table 1 classifies the beneficiaries 
under three broad categories: unrestricted; restricted non-users; and direct users. Transportation improvements create benefits for the unrestricted general public within a region/jurisdiction if they lead to economic or social returns signified by an increase in general taxation. However, while such improvements may be funded from general tax revenue, disentangling the general public benefit from that received by individuals is difficult. Where transportation benefits are more directly enjoyed by direct users of transportation facilities (e.g., drivers or passengers), this supports the use of financial instruments such as fuel taxes or congestion charges for the former and fares/permits for the latter.

Two PPPs that highlight the problems of charging users are the Skye Bridge and Dartford (or Queen Elizabeth II) Bridge. Whilst the latter was seen as less controversial than the former, which according to Shaoul et al. (2011) is 'a political and financial debacle' (p. 57), in both cases the tolls were higher than they would have been had the projects been financed by public debt. Indeed, following persistent public complaints, the Scottish Executive bought out the Skye Bridge contract and removed the tolls.

Between the general public and direct users, there is a restricted non-user beneficiary group who benefit from transportation value creation because of their location (e.g., property owners or developers); accordingly, they are the targeted contributors of VC. The final column of Table 1 shows the cost types (upfront capital or operating and maintenance) that can be financed by the finance instruments. Ideally, the cost types should be matched with the timing of transportation benefits. As direct users receive most of the benefit from usage, the corresponding revenues are primarily suitable for operating and maintenance costs; however, as the growth of the general tax base occurs over the life of a transportation facility, the increases in general taxation may be appropriate for funding both cost types. For property owners and developers, as the gains from enhanced locational advantages are realised mostly upon completion of transportation facilities, VC policies are typically applied to capital costs. For example, negotiated exactions are often only used to reduce the fixed cost for the right-ofway. However, as transportation utility fees are more closely related to usage they may be more suitable for operating and maintenance costs. 
Table 1

Funding Mechanisms and Finance Instruments

\begin{tabular}{|c|c|c|c|c|c|c|}
\hline Funding & & & & & & \\
\hline \multirow[t]{3}{*}{ Mechanisms } & \multicolumn{2}{|c|}{ Beneficiaries } & \multirow[t]{3}{*}{ Benefit Measurement } & Finance Instruments & \multicolumn{2}{|c|}{ Cost Types } \\
\hline & & & & & Upfront & Operating and \\
\hline & & & & & Capital & Maintenance \\
\hline $\begin{array}{l}\text { General tax } \\
\text { revenue }\end{array}$ & Unrestricted & General public & $\begin{array}{l}\text { Increase in general } \\
\text { taxation }\end{array}$ & $\begin{array}{l}\text { Sales and income } \\
\text { taxes }\end{array}$ & $\checkmark$ & $\checkmark$ \\
\hline \multirow{6}{*}{$\begin{array}{l}\text { Value } \\
\text { capture }\end{array}$} & Restricted non-users & Property owners & Land value growth & Land value tax & $\checkmark$ & $\checkmark$ \\
\hline & & & Property tax growth & $\begin{array}{l}\text { Tax increment } \\
\text { financing }\end{array}$ & $\checkmark$ & \\
\hline & & & $\begin{array}{l}\text { Assessed special } \\
\text { benefits }\end{array}$ & $\begin{array}{l}\text { Special assessment } \\
\text { district }\end{array}$ & $\checkmark$ & \\
\hline & & & Transportation utility & $\begin{array}{l}\text { Transportation } \\
\text { utility fees }\end{array}$ & & $\checkmark$ \\
\hline & & Developers & $\begin{array}{l}\text { Off-site development } \\
\text { opportunities }\end{array}$ & $\begin{array}{l}\text { Development impact } \\
\text { fees }\end{array}$ & $\checkmark$ & \\
\hline & & & $\begin{array}{l}\text { Off-site access } \\
\text { benefits }\end{array}$ & $\begin{array}{l}\text { Negotiated } \\
\text { exactions }\end{array}$ & $\checkmark$ & \\
\hline
\end{tabular}




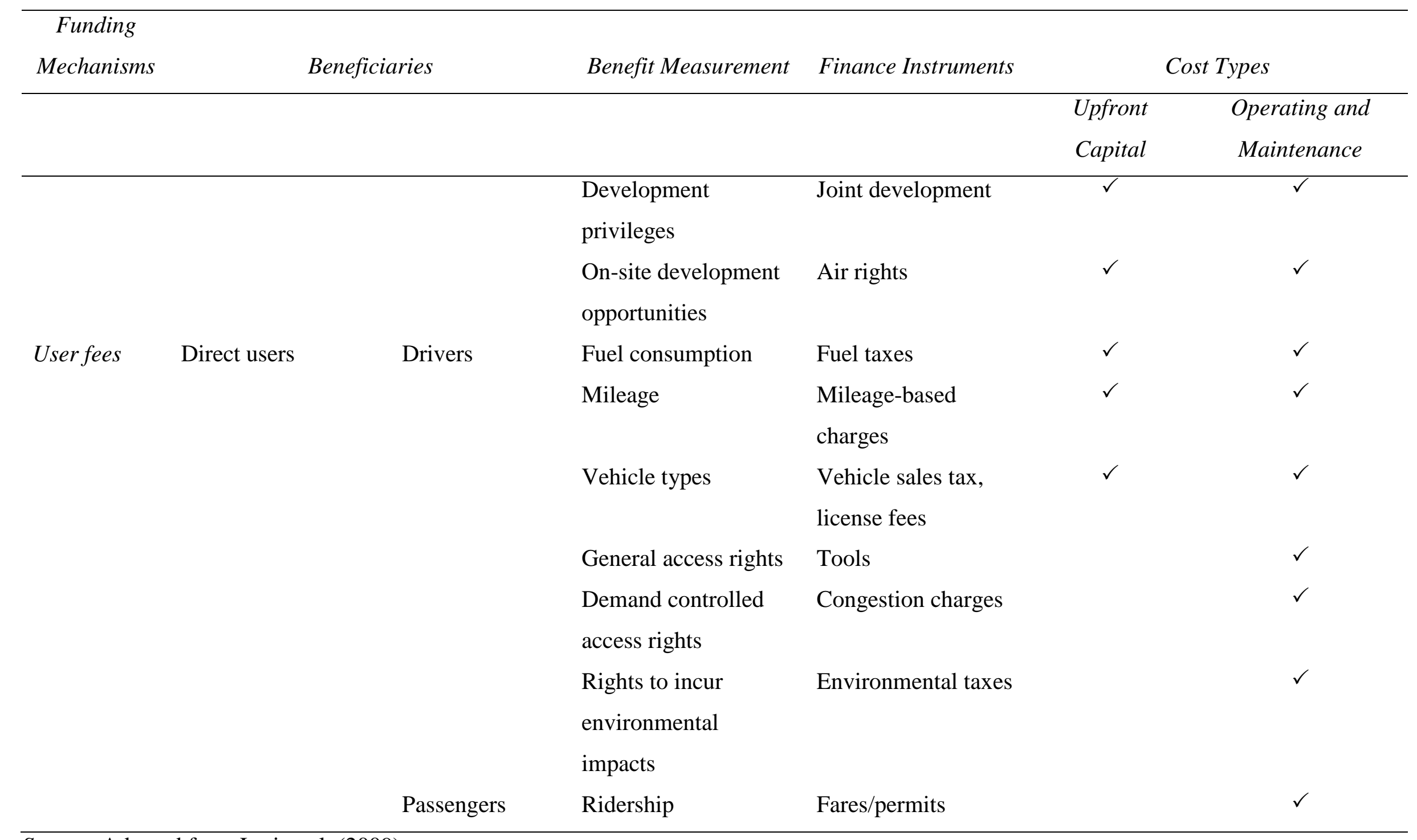

Source: Adapted from Lari et al. (2009) 
As transportation improvements may create value in different ways simultaneously, the VC finance instruments shown in Table 1 can be applied individually or combined to suit specific circumstances. However, the total level of VC cannot exceed the total benefits created; otherwise the finance instruments would negate the economic rationale of development. Drawing upon relevant literature (e.g., GVA Grimley, 2004; CTOD, 2008; Lari et al., 2009; Levinson and Istrate, 2011), the VC finance instruments which arise in the case studies (Land Value Tax, Tax Increment Financing, Special Assessment District, Development Impact Fees and Joint Development) are now described and evaluated on the basis of whether they are economically efficient, equitable, sustainable and feasible.

Economic efficiency relates to the instrument's ability to allocate resources efficiently, and refers not only to its capacity to equate marginal benefits and costs of development but also to user charges. Equity addresses the fairness of resource allocation (e.g., the distribution of benefits across different social strata and how the finance burden is allocated across various income groups). Sustainability considers whether the instrument is a reliable source of revenue in terms of its adequacy, growth potential, stability and predictability. Finally, feasibility is evaluated in terms of each instrument's political acceptability and administrative ease.

\section{Land Value Tax (LVT)}

This impacts on property owners and reforms property tax by separating the value of a property associated with land from that associated with the building. As LVT is levied to capture the general increase in land values due to improved accessibility from transit networks, it is more appropriate for funding a comprehensive programme than a single project. Globally, this is the most commonly applied VC instrument, having been adopted in Canada, Australia and New Zealand, and to a lesser extent in the USA.

- Economic efficiency - a strong case can be made on efficiency grounds as contributions towards the financing are aligned with the benefits derived by landowners in the form of higher values. Although a pure land tax is preferred to one on buildings due the fixed supply of land, this is rare as land taxes are likely to be slightly regressive in terms of ability-topay (equity) and may prove politically challenging due to their high visibility and potential unpopularity (feasibility). Consequently, the most common form of LVT is a split-rate tax that charges land at a higher rate than buildings as taxing land at a higher rate results in little economic distortion because its supply is fixed.

- $\quad$ Equity - the primary beneficiaries of LVT are office property owners in high land value locations and owners of single-family homes in middle- and upper-class neighbourhoods. 
While LVT tends to produce favourable results in terms of benefit equity, it is likely be slightly regressive in terms of ability-to-pay.

- Sustainability - LVT can provide a sustainable revenue source, with its broad base meaning that a fairly low tax rate is adequate. While the growth potential is modest, LVT is fairly stable and resistant to economic cycles; although recent housing market troubles suggest that major corrections in property prices, though rare, might limit its value as a countercyclical revenue instrument.

- Feasibility - administratively, while LVT is fairly easy to implement, accurately determining the value of land and buildings separately can be challenging. Pressures from landowners to reassess property values downward can make LVT difficult politically, especially given its high visibility.

Tax Increment Financing (TIF)

Under TIF a region targets a district, usually an established neighbourhood, for economic development and finances this through property tax revenues generated from the growth in the district's assessed property values. TIF is self-financing because it permits new development without reducing regional tax revenues. Once the project is completed and the TIF bond repaid, the tax base is restored. TIF is used widely in the USA and is being employed in Scotland (Scottish Futures Trust, 2011).

- Economic efficiency - this is dependent on whether the project delivers local benefits in the form of property value appreciation. Regarding transportation, TIF may be more suitable for subway/elevated systems as these operate at higher average speeds and serve more densely populated locations than light rail or streetcar networks and consequently create larger increments in land value. Concerning general economic development, while property values may increase within a TIF district, this localised effect may come at the expense of growth in the larger jurisdiction.

- Equity - requiring those who receive a disproportionate benefit from transportation improvements to make greater contributions towards its financing promotes benefit equity. Where property taxes are used as the basis for TIF financing, those generated within the district are not available to overlapping jurisdictions. Hence, adjoining areas may face pressure to provide increased services without any corresponding increase in revenues. Moreover, TIF typically does not operate on the basis of ability-to-pay. For example, if a transportation improvement creates appreciation in local residential property values, TIF 
districts may place an increased burden on lower/fixed-income households, either directly through property tax increases or indirectly through rent increases.

- Sustainability - the revenue base for TIF is limited as it is typically applied to a specific location near a transportation improvement. However, as a project-specific financing technique, it should be suitable.

- Feasibility - in terms of political feasibility, as TIF-financed projects are generally perceived to 'pay their own way' this tends to increase public acceptance. However, their administrative feasibility is less compelling given their establishment and operation involves compliance with time-consuming legal requirements, especially where bond financing is involved.

\section{Special Assessment District (SAD)}

At a time when increasing expectations are being placed on government finances and public service provision, a $\mathrm{SAD}^{5}$ provides an opportunity to widen local choice by promoting partnership between business and local government to develop projects and services within a clearly defined commercial area (Belfast City Council, 2007). It involves charging property owners (typically businesses) within designated areas an agreed levy based on the property's rateable value to fund infrastructure development fully or partially. The rationale is that the investment will generate benefits for the areas' businesses because the value of land and property will rise, together with region's population which will increase the customer base. Legislation enabling the establishment of such districts has been passed in England, Wales, Scotland and the Republic of Ireland.

- Economic efficiency - depending on the basis for setting the charge (e.g., distance from transportation facility or store frontage), using a SAD to apportion the cost of transportation improvements among direct beneficiaries can enhance economic efficiency.

- Equity - benefit equity may be enhanced if the cost of transportation improvements is allocated to property owners in proportion to benefits received. While this can help rectify geographic inequities that exist when general taxes are used, much depends upon how the assessments are structured. For example, entire classes of properties (such as residential) may be exempted, although this does create the potential for some beneficiaries to freeride on others' contributions. 
- Sustainability - as a SAD tends to have a narrow base and raise limited revenue, it is unlikely to be an appropriate replacement for large-scale transportation revenue sources. However, SAD revenue can make an important contribution, especially to a project's cost.

- Feasibility - a SAD is highly visible and affected property owners will need to be convinced of its value or necessity before charges become politically feasible. Moreover, administratively, a SAD may be difficult due to the need to establish legally defensible methods of calculating assessments; however, once in place, it is relatively easy to operate.

\section{Development Impact Fees (DIF)}

This is a one-off fee levied on developers wishing to build in a particular area. The fee is used to defray the cost of expanding public services and utilities. While DIF is similar to negotiated exactions, the difference is that DIF can be levied for off-site services such as local roads, schools or parks. This technique works on the principle that government provides infrastructure and land development consumes it. DIF works better when there are many developers, none of whom has the scale to complete a joint development alone, and, in the context of transit, where there is a dispersed origin and destination pattern. While DIF is employed widely throughout the USA, its use as a means of financing transportation infrastructure is a recent phenomenon.

- Economic efficiency - DIF has the potential to improve the efficiency of resource distribution by allocating most of the new development infrastructure costs to those most likely to benefit. Thus infrastructure users should receive price signals as to the cost of infrastructure provision.

- Equity - those who contribute to the financing of new infrastructure through DIF should receive roughly proportional benefits. While issues of geographic equity should be minor, DIF is usually not set with regard to ability-to-pay. An unintended effect is that builders in desirable markets may ignore lower-income households and focus on higher-income segments if they are unable to recover DIF costs.

- Sustainability - the revenue base of DIF is narrow since it is often targeted at new development; although, as it is rarely the primary source of revenue, it can replace a portion of general taxation and be readjusted fairly easily to take account of changes in income or inflation. However, if projected growth rates do not materialise, the narrower base may leave local jurisdictions exposed to significant financial risk.

- Feasibility - DIF should be politically acceptable as it is not highly visible since the cost is usually bundled into the price of new development; administratively, it is relatively easy 
to implement. Existing residents may favour DIF as it shields them from development costs, from which they may benefit. Developers may be less supportive, depending upon demand and their ability to recharge costs.

\section{Joint Development (JD)}

This is the development of a transit facility and an adjacent private property in which a private sector partner either provides the facility or makes a financial contribution to offset its costs. Private sector payments may take several forms, including a one-off lump sum for development rights, annual lease payments, financial contributions to station construction costs and fees from retailers that are connected to the station. There are several prominent JD examples in eastern Asian cities such as Hong Kong and Tokyo that have extensive railway systems, whose expansion is often tied to new property development.

- Economic efficiency - as evidenced by their willingness to pay, the contributions of developers or tenants will coincide with their anticipated benefits from locating near a transportation facility.

- Equity - since this involves voluntary transactions, it ensures benefit equity among participants. In terms of ability-to-pay, JD projects often attract higher-end commercial tenants, to the extent that JD costs are not transferred to lower-income customers or employees. Similarly, as residential tenants tend towards the middle to the upper end of the income scale, this implies a distribution of costs that is neutral to progressive with respect to ability-to-pay.

- Sustainability - as the revenue base is fairly narrow, JD is unlikely to replace more traditional sources.

- Feasibility - the narrow base and low visibility makes JD politically palatable to most residents. As JD will only be possible if the private sector anticipates an incremental benefit, it will not always be feasible. JD agreements are administratively complex and thus their transaction costs could be higher than other VC instruments.

\section{METHODOLOGY}

As case studies are empirical enquiries that investigate a contemporary phenomenon within its real-life context (Yin, 2003), they provide the opportunity to learn from real-life examples and 
are vital in understanding social phenomena where an appreciation of context is important (Cooper and Morgan, 2008). The use of case studies in this context was considered appropriate as they provided examples of VC in operation and facilitated a cross-country comparison between the USA and UK.

\section{CASE STUDIES}

\section{Wilson Yard, Chicago}

Chicago's 'L', or elevated, trains, was privately run until 1947when the Chicago Transit Authority (CTA) took over its operation. The CTA's costs rose rapidly throughout the 1970s and transit provision became increasingly difficult with rapid auto-dependent, low-density suburbanisation. With passenger numbers at their lowest in the 1990s, the service was cut drastically. TIF is used in Chicago, with funds are generated by the growth in the Equalized Assessed Valuation (EAV) of properties within a designated district over 23 years. Under state law, areas proposed for TIF designation must possess a range of blighting factors including: age; excessive vacancies; inadequate utilities; and lack of community planning. When an area is declared a TIF district, the amount of property tax it generates is set as a base EAV amount. As property values increase, property tax growth above the EAV base is used to either repay bonds issued to pay upfront costs and/or operating and maintenance costs. At the conclusion of the 23-year period, the increase in revenue over the base amount is distributed annually among the city's taxing bodies.

Wilson Station is on the Red Line, Chicago's main and busiest ' $L$ ', and earned a reputation as one of the worst CTA-run rail stations. The Wilson Yard TIF district, a 144-acre site, was created in 2001. The area was home to several ethnic groups who moved in during the 1970s and 1980s. By 1990, about one-third of the residents were foreign-born and low-income, with the area suffering from deteriorating buildings and traffic congestion. However, recently, the neighbourhood has gentrified and property prices have risen.

- Economic efficiency - Wilson Station is an important feature of the Wilson Yard TIF district. Since funds were needed to refurbish the station, the use of TIF was welcomed by most residents. By improving access to the neighbourhood and increasing transportation options, the refurbished Wilson Station also promoted horizontal equity. For example, businesses benefited from the increased foot traffic, and college students and staff enjoyed 
safe and improved access to campuses. The use of TIF was also vertically equitable as those on low incomes are more likely to be dependent on public transportation. However, TIF has been criticised for using public funds to deliver projects that would have been provided by the private sector. Naccarato (2007) estimates that Chicago lost over \$250 million of revenue in 2002 from TIF-funded projects that would have proceeded anyway.

- Equity - in Chicago, DIF, which increased with distance in the suburban area around the Chicago business district, were also applied. However, they were negatively associated with older housing, unemployment and poverty. While Chicago suburbs with lower incomes, larger minority populations and greater poverty had an interest in promoting rather than reducing growth, the added charges for infrastructure development reduced the incentive to develop in those areas.

- $\quad$ Sustainability - the Wilson Yard TIF district has generated substantial revenues which have funded several projects. The impact of the economic downturn was minimal, with slight revenue dips in 2007 and 2009. Overall, annual revenues grew more than twofold from approximately \$3 million in 2002 to \$7 million in 2010.

- Feasibility -significant institutional capacity was available to form and administer the TIF district, and there was no significant opposition to using TIF for station redevelopment.

\section{Portland Central Streetcar Project}

In the 1980s/early 1990s, downtown Portland was dominated by dilapidated warehouses and offices. The Portland Central Streetcar Project was intended to link Portland's neighbourhoods with quality transportation and to spur development along the streetcar lines. Four streetcar lines (Blue, Green, Red and Yellow) were built in a series of five separate projects, funded by various VC instruments. The Red line involved building a light rail system connecting downtown Portland to Portland International Airport (Portland Streetcar Inc., 2008). In 1997, Bechtel Enterprises (a construction company) approached the City of Portland, Port of Portland (the entity overseeing the airport) and Tri-County Metropolitan Transportation District of Oregon (TriMet) with plans to jointly develop the Red line and Cascade Station, a 120-acre plot of government-owned land on the way to the airport. In 1999, Port of Portland, City of Portland, Portland Development Commission and TriMet signed a \$125.8 million JD agreement to build a 5.5-mile light rail extension with four stations.

The scheme was financed as follows: Port of Portland $\$ 28.3$ million, funded by a \$3 passenger charge (levied on airlines for each passenger boarding through the airport); the City 
of Portland \$23.8 million, through TIF; TriMet \$45.5 million, from general taxes; and Bechtel contributed \$28.2 million. In return, Bechtel received an 85-year lease to develop Cascade Station, without paying rent and the $\$ 125$ million design-build construction contract for the light rail without entering a bidding process.

Two factors that created the Cascade Station development opportunity were its designation as a TIF district and Portland's Urban Growth Boundary (UGB) regulations ${ }^{6}$. Property tax collections within the district are divided into two parts: taxes applied to the district's assessed value at the time it was created; and taxes applied to the increase in value after its creation. Taxes collected on the frozen tax base continue to be distributed to all taxing jurisdictions; taxes collected on the increased value are only collected for reinvestment in the area. This enabled Portland to use TIF to fund its contribution to the project. The Portland UGB has resulted in higher land values and smaller land parcels in the city and Portland's population growing by $50 \%$ since 1973 , while its land area has only grown by $2 \%$.

- Economic efficiency -properties within two blocks of the line realised $75 \%$ to $90 \%$ of the FAR (floor area ratio - a measure of density) allowed, compared with development at 43\% of FAR potential for properties located more than three blocks from the line. The higher density of development for the closer properties translates to higher property values and tax revenues. Many areas near the line saw increases in property value in excess of $400 \%$ between 2003 and 2008, and by 2008 there was \$3.5 billion of new development along the route (Brookings Institution, 2009).

- Equity - to address the 'beneficiaries pay' principle, residential properties were charged half the rate of that imposed on commercial ones (Portland City Council, 2009). The use of TIF advanced horizontal equity as the funds were used to finance capital expenditure within the district. Furthermore, to the extent that lower-income people benefited more from transit than higher earners, vertical equity was enhanced.

- $\quad$ Sustainability - TIF districts involved in funding the project were impacted by the housing market downturn, especially where condominiums constituted a large portion of the new development.

- Feasibility - Oregon's legislation allows TIF and SAD to be used for transportation projects. Through consultation, Portland received broad-based stakeholder support for their formation. Furthermore, the city was able to work with stakeholders to find solutions when problems arose. For example, it averted a political battle by exempting owner-occupied residential properties from paying assessments. The bond issuance, preliminary studies, fee 
assessment, public relations management and other activities involved in TIF and SAD administration demand significant staff time and resources; in Portland, the institutional capacity to administer these existed.

\section{Crossrail}

This major infrastructure project consists of a high-frequency, high-capacity east-west train link across London, which is estimated to deliver up to 14,000 jobs between 2013 and 2015 when the construction phase reaches its peak and generate $£ 1.24$ billion annually for the London economy by 2026 (Greater London Authority (GLA), 2010). It is anticipated that Crossrail will bring an additional 1.5 million people within 45 minutes commuting distance of key business districts and that approximately 200 million passengers will travel on Crossrail annually (Crossrail, 2012).

The estimated cost of Crossrail was originally $£ 15.9$ billion (Hill, 2009). Following the 2011 Comprehensive Spending Review, the Coalition Government revised the operational start date from 2017 to 2018 and approved $£ 1$ billion of cost savings. GLA's and Transport for London’s (TfL) contribution is approximately $£ 7.15$ billion which is to be funded as follows: $£ 4.1$ billion from a new business rates supplement (equivalent to LVT) (Gregory and Dawber, 2012); £300 million from a Community Infrastructure Levy (CIL) (similar to DIF) on new developments across London; and Section 106 contributions of $£ 300$ million (similar to JD).

The business rates supplement has two components: $£ 3.5$ billion to be paid by the GLA through borrowings; and $£ 0.6$ billion in direct contributions, which equates to the amount by which the income raised exceeds the financing cost of borrowing. The business rates supplement is fixed at $2 \%$. Beginning in 2010 to correspond with the drawdown of the initial borrowings, it is levied on nondomestic London properties with a rateable value of over $£ 55,000$ (equivalent to a SAD), with the chargeable period estimated to be between 24-31 years (GLA, 2010). Under a Section 106 agreement (of the Town and Country Planning Act 1990), the developer's contribution towards the CIL is based upon the increase in land value arising from the granting of planning permission (Saxer, 2000). The principle behind the CIL is that Crossrail represents a sizable contribution to London's transit system; equivalent to a $16 \%$ increase in capacity for the whole underground and rail network. Furthermore, it is envisaged that Crossrail will generate wider benefits as even those developments in areas not served by Crossrail should gain from the improved capacity, connectivity and general economic growth. 
- Economic efficiency - as the business rates supplement falls on those businesses likely to benefit from the transit infrastructure, the contributions are aligned to some extent with the benefits derived in the form of higher property values.

- Equity - the business rates supplement is a flat tax levied on all non-domestic properties regardless of their location. It therefore falls on those businesses that stand to benefit as well as those who will see little benefit, and even those who may be placed at a competitive disadvantage as a result of new transport patterns.

- Sustainability - the projected revenue raised through the business rates supplement is based upon the assumption that rateable values will increase by $15 \%$ every five years (except in the first five years when a growth rate of $6 \%$ is assumed). Whether this is realistic in the current economic climate is debatable.

- Feasibility - similar to the Portland Project, the legislative framework through the Crossrail Act 2008 paved the way for the project and enabled the various finance instruments to be enacted.

\section{The Northern Line Extension}

This £950m project, which will extend one of London Underground’s oldest lines, includes two extra stations, and will subsequently connect an existing station with the Battersea area (TfL, 2012). An innovative funding package has been agreed under which the GLA will borrow the cost of development from the Public Works Loan Board, with the government guaranteeing the repayment to minimise borrowing costs. The loan will be repaid by revenue raised from local regeneration projects benefitting from the new transport links. The two sources of revenue will be contributions from developers under Section 106 agreements or CILs; and the growth in business rates revenue from a new enterprise zone (similar to a TIF district), which will stay in operation for at least 25 years. While an enterprise zone usually offers businesses a rates discount to stimulate growth and investment, in this instance it is used purely as a mechanism to fund the Northern Line extension. It is anticipated that the local economy will benefit from the creation of 25,000 new jobs and 16,000 new homes (TfL, 2012).

The Local Government Finance Act 2011 enabled local authorities in England and Wales to retain a portion of any increase in business rates within their jurisdiction and gave councils the opportunity to invest on the basis of their potential share of such an increase. In this case, Battersea and Wandsworth Councils are able to borrow against future tax revenue to provide 
up-front project funding. In addition, in the 2011 National Infrastructure Plan (HMT, 2011), the government stated that it would consider allowing local borrowing against future receipts of a CIL.

- Economic efficiency - much depends on whether the project delivers benefits locally through property value appreciation; however, the prospects are positive since subway systems operate at higher average speeds than light rail networks and serve densely populated locations, thus they are likely to create large land value increments. Although, general economic development can be limited if investment is steered towards less productive locations.

- Equity - as the project is being financed by developers and businesses, those who will receive disproportionate benefit from the project will be responsible for financing the improvements. However, this may not take account of ability-to-pay and developers may focus on high-income segments of the market if they are unable to recover the CIL costs. Furthermore, as property taxes are being used as the basis for financing, the taxes generated within the enterprise zone are not available to overlapping jurisdictions, which may face pressure to provide increased services without any corresponding increase in revenues.

- $\quad$ Sustainability - the revenue base is limited as it applies to a specific location. While if projected growth rates do not materialise, leaving the councils exposed, the government has guaranteed the loan repayment.

- Feasibility - the plans were welcomed by local residents, with around three quarters of those responding to the third public consultation returning positive or neutral comments. Additionally, in terms of political feasibility, the financing of the project was facilitated by the Local Government Finance Act 2011. Although, while the 2012 Budget committed investment towards TIF projects of up to $£ 150$ million, with money available from 20132014, the number of TIF schemes that are allowed will initially be limited (HMT, 2012b).

\section{DISCUSSION AND CONCLUSION}

Whilst the concept of VC is not totally alien to the funding of PPPs in the UK, or countries such as Australia, Poland and Portugal (McIntosh, 2011; Medda and Modelewska, 2011; Martínez and Viegas, 2012), it is more widely applied in the USA. Notwithstanding, the concept that those who either directly or indirectly benefit from infrastructure development should share 
some of the financial burden seems fairer than servicing debt from general taxation as traditionally occurs with PPP projects. Charging all taxpayers contradicts the benefit principle, whereby all benefits from public expenditure are 'both measurable and allocable to individual households' (Meerman, 1980, p.45). Hansjurgens (2000) contrasts this with the ability-to-pay principle, when no evaluation of 'both the benefits of public expenditures and the corresponding tax burden' (p. 97) is taken by taxpayers. Whilst the emphasis in this paper has been on rail networks, VC applies equally well to roads (Batt, 2001). Therefore if governments around the world wish to stimulate economic recovery via a capital investment programme using PPPs, they should implement schemes which can be funded by those benefitting from various projects. Such Keynesian views about public spending during recessionary periods liberates politicians to build up budget deficits and supports Buchanan's (1987) view that people suffer from "fiscal illusion” and prefer debt to taxation. However, given Buchanan's assertion that it is immoral for one generation to burden another for its own benefit, VC transfers some of the cost of infrastructure projects to those who benefit, either directly or indirectly.

This paper presents five VC finance instruments: LVT, TIF, SAD, DIF and JD. Some of these target property owners, while others target developers. Moreover, the instruments differ in how, when and where they may be utilised. They can be applied individually or combined to meet specific situations, and they also yield different outcomes, which can be assessed relative to four criteria: economic efficiency, equity, sustainability, and feasibility. An evaluation of the finance instruments employed in each of the case studies is summarised in Table 2.

\section{Table 2}

Summary of Case Study Finance Instruments

\begin{tabular}{lcccc}
\hline & $\begin{array}{c}\text { Economically } \\
\text { Efficient }\end{array}$ & Equitable & Sustainable & Feasible \\
\hline Wilson Yard, Chicago [TIF] & Yes & Mixed & Yes & Yes \\
PortlandCentral Streetcar & & & & \\
Project[SAD, TIF] & Yes & Yes & Mixed & Yes \\
Crossrail [DIF, LVT \& SAD] & Yes & Mixed & Mixed & Mixed \\
Northern Line Extension [DIF, & & & & \\
JD \&TIF] & Mixed & Mixed & Yes & Yes \\
\hline
\end{tabular}


Drawing upon the literature and the case studies presented above, a number of issues relevant to those considering the use of VC are highlighted. TIF typically does not generate additional tax revenues; rather it transfers them from one administrative area to another. Moreover, while TIF-funded projects can stimulate growth, if property values do not increase, taxpayers can end up funding a project which they assumed would only proceed if financed by local businesses. Furthermore, the use of TIF requires significant institutional capacity, community support and agreement among taxing authorities. Notwithstanding, the use of TIF is growing in England with projects planned in Sheffield, Leeds and Manchester, together with six projects underway in Scotland (Gregory and Dawber, 2012; Ward, 2012; Gordon, 2013).

The evidence suggests that a SAD can only succeed where a genuine PPP exists based on a clear, focused and measurable business plan, together with trust amongst the private and public sector parties illustrated by the existence of engagement and funding in advance of the SAD development (Mitchell, 2008). SADs must be carefully designed and implemented to minimize inequities; moreover, greater engagement and dialogue might not necessarily mean the additional tax burden on business will be accepted. Where the conditions are right, a levy up to $1 \%$ of the rateable value is generally acceptable to businesses (Belfast City Council, 2007); levies greater than this have yet to gain the broad support of UK retailers and trade organisations, with $88 \%$ of levies being $2 \%$ or less (Sandford, 2013). Examining the processes through which SADs have travelled from the USA to the UK, Cook (2008) highlighted that they were much smaller in scale than those in the USA and stressed the complexities associated with replicating policies adopted in one jurisdiction in another.

While each of the VC instruments discussed could potentially be used to fund transit projects, their successful application, either individually or in combination, depends on factors such as the enabling environment, stakeholder support and institutional capacity. For example, a robust legislative framework is required for JD, DIF and TIF, and VC works best if local communities hold genuine dialogue and create an environment where further engagement can take place. Neighbourhood residents are often the most affected by TIF-produced changes and businesses need to be closely engaged in decisions to introduce supplementary rates or SADs. Thus a regional framework of support is required to establish partnership structures and maintain their effectiveness. Consequently it is imperative that there is a buy-in from the business community and government agencies to ensure commitment to meeting the long-term needs of, for example, SADs as a delivery mechanism for economic development and regeneration. Moreover, significant staff time and resources are required to administer VC instruments such as TIF and SAD, while clear policy guidelines are needed to undertake JD. 
According to HMT (2012a), experience of past PPPs suggests that a number of aspects are not working effectively, including a lack of transparency of the future liabilities created by PPPs, which has led the Government to take steps to address these concerns. These include publishing Whole of Government Accounts (WGA) in order to improve the transparency of PPP liabilities. These show that the liability for future capital payments for 2011/12 was £36.1 billion (increasing from $£ 28.1$ billion in 2009/10 and £32.0 billion in 2010/11) (Office for Budget Responsibility (OBR), 2013). Although, given the recognition of assets and liabilities in the National Accounts is based upon who bears most of the financial risk, rather than on who has effective control as with WGA (Heald and Georgiou, 2011; OBR, 2013), the figure provided in the National Accounts for 2011/12 was $£ 5$ billion. As the underlying principle of VC is that those who benefit pay, PPPs funded in this manner should reduce the level of financial liabilities for future taxpayers. As illustrated in Table 1, VC mechanisms can be used to fund capital and/or operating and maintenance costs, therefore while the overall funding requirement may be similar to that for existing PPPs, the principle of who services this liability is different. However, this does not alleviate the need to adequately account for these shifting liabilities nor remove the challenge of forecasting and measuring value change (e.g., for example increases or otherwise in land and property) to provide confidence around future revenue flows.

Despite the challenges outlined above, if, as its proponents claim, those owning land, property or business in an area where a station or road access point is to be built will gain financially, it seems fair that they should contribute to the financing of this investment. Given the boundary issues referred to above (e.g., TIF and SAD), consideration should be given to employing such instruments across a number of local authorities. As both residential and commercial property owners in the vicinity of transport improvements may profit, and whilst a certain amount of resistance is to be expected, there has to be recognition that any profiteering is not possible without a public contribution in some form. It is therefore recommended that policy makers review the fiscal incentives associated with the various VC funding instruments to ensure they create the right incentives for sustainable long-term investment.

\section{NOTES}

1 HMT (2012a) announced a new approach to PPPs, dubbed PF2, with one of the proposed reforms being an increase in equity financing to $20-25 \%$ in order to encourage new sources of long-term funding from capital markets and institutional investors. 
2 Monoline insurers focus on operating in one specific financial area and give investors and issuers confidence to participate in the market by providing financial protection. Bonds insured by these companies are sometimes said to be "wrapped" by the insurer.

3 These are short-term finance instruments used to pay off income-producing construction or commercial properties, usually repayable in three to five years.

4 A school of economists characterised by a belief that government policy should not interfere with the operation of natural economic laws and that land is the source of all wealth.

$5 \quad$ Also known as Benefit Assessment District, Business Improvement District (BID) and Local Improvement District (LID). The term SAD is used throughout this paper.

6 A UGB is a mapped line that separates land that can be developed from land where development is prohibited, to promote density, stop sprawl and protect farmland.

\section{REFERENCES}

Andelson, R. (1979), Critics of Henry George: A Centenary Appraisal of Their Strictures on Progress and Poverty (London: Associated University Press).

Barney, J. (1991), 'Firm Resources and Sustained Competitive Advantage', Journal of Management, Vol. 17, No. 1, pp. 99-120.

Batt, W. (2001), 'Value Capture as a Policy Tool in Transportation Economics: An Exploration in Public Finance in the Tradition of Henry George', American Journal of Economics and Sociology, Vol. 60, No. 1, pp. 195-228.

BBC (2009), Timeline: Credit Crunch to Downturn (http://news.bbc.co.uk/1/hi/business/7521250.stm).

_ (2010), School Buildings Scheme Scrapped (http://www.bbc.co.uk/news/10514113). (2011), Multi-Billion Pound Push on UK Economy (http://www.bbc.co.uk/news/uk15914145).

Belfast City Council (2007), Belfast: State of the City (The Development Brief, Policy and Research Unit, Development Department, Belfast City Council).

Broadbent, J., J. Gill, and R. Laughlin (2003), 'Evaluating the Private Finance Initiative in the NHS in the UK', Accounting, Auditing and Accountability Journal, Vol. 16, No. 3, pp. 422-45.

(2008), 'Identifying and Controlling Risk: The Problem of Uncertainty in the Private Finance Initiative in the UK's National Health Service', Critical Perspectives on Accounting, Vol. 19, No. 1, pp. 40-78.

Brookings Institution (2009), Value Capture and Tax-Increment Financing Options for Streetcar Construction (Washington DC: Brookings Institution). 
Buchanan, J. (1987), "Budgetary Bias in Post-Keynesian Politics: The Erosion and Potential Replacement of Fiscal Norms”, in J. Buchanan, C. Rowley, and R. Tollison (eds.), Deficits (Oxford: Basil Blackwell), pp. 180-95.

Center for Transit-Oriented Development (2008), Capturing the Value of Transit, November (Berkeley, CA).

Cervero, R. (1994), 'Rail Transit and Joint Development: Land Market Impacts in Washington, D.C. and Atlanta', Journal of the American Planning Association, Vol. 60, No. 1, pp. 8397.

Christensen, P. (1989), 'Historical Roots for Ecological Economics', Ecological Economics, Vol. 1, No. 1, pp. 17-36.

Connolly, C. and A. Wall (2011), 'The Global Financial Crisis and UK PPPs’, International Journal of Public Sector Management, Vol. 24, No. 6, pp. 533-42.

Cook, I. (2008) 'Mobilising Urban Policies: The Policy Transfer of US Business Improvement Districts to England and Wales', Urban Studies, Vol. 45, No. 4, pp. 773-95.

Cooper, D. and W. Morgan (2008), 'Case Study Research in Accounting', Accounting Horizons, Vol. 22, No. 2, pp. 159-78.

Crossrail (2012), Discover the Crossrail Route (http://www.crossrail.co.uk/route/).

Edwards, P. and J. Shaoul (2003), 'Partnerships: for Better for Worse?', Accounting, Auditing and Accountability Journal, Vol. 16, No. 3, pp. 397-421.

Froud, J. and J. Shaoul, (2001), ‘Appraising and Evaluating PFI for NHS Hospitals’, Financial Accountability \& Management, Vol. 17, No. 3, pp. 247-70.

Gordon, A. (2013), 'Back in Vogue: Is Light Rail Set for Another Golden Age?,Surveyor, 24 June, (http://www.transport-network.co.uk/Back-in-vogue-Is-light-rail-set-for-anothergolden-age/9024).

Greater London Authority (2010), Intention to Levy a Business Rate Supplement to Finance the Greater London Authority's Contribution to the Crossrail Project - Final Prospectus (http://www.london.gov.uk/sites/default/files/finalprospectus.pdf).

Gregory, D. and H. Dawber (2012), Financing for Growth: A New Model to Unlock Infrastructure Investment (London: The ResPublica Trust).

GVA Grimley (2004), Developing a Methodology to Capture Land Value Uplift around Transport Facilities, October, Scottish Executive, (http://www.scotland.gov.uk/Publications/2004/11/20385/48339).

Hansjurgens, B. (2000), 'The Influence of Knut Wicksell on Richard Musgrave and James Buchanan', Public Choice, Vol. 103, Nos. 1/2, pp. 95-116. 
Heald, D. (2003), 'Value for Money Tests and Accounting Treatment in PFI Schemes', Accounting, Auditing and Accountability Journal, Vol. 16, No. 3, pp. 342-371.

Heald, D. and G. Georgiou (2011), 'The substance of accounting for public-private partnerships’, Financial Accountability \& Management, Vol. 27, No. 2, pp. 217-247.

Her Majesty’s Treasury (2006), PPP: Strengthening Long-term Partnerships (Norwich: The Stationery Office).

_ (2009), Safeguarding Government Infrastructure Investment (Press Notice PN/00/00).

_ (2011), National Infrastructure Plan 2011 (Norwich: The Stationery Office).

_ (2012a), A New Approach to Public Private Partnerships (London: The Stationery Office). (2012b), Budget 2012 (Norwich: The Stationery Office).

Hill D. (2009), 'Crossrail Guarantee', The Guardian, 1 October (http://www.guardian.co.uk/uk/davehillblog/2009/oct/01/sadiq-khan-pledges-crossrailfunding-boris-johnson?INTCMP=ILCNETTXT3487).

KPMG (2009), The Use of Mini-Perms (Dublin: KPMG).

Lari, A., D. Levinson, Z. Zhao, M. Iacono, S. Aultman, K. Das, J. Junge, K. Larson and M. Scharenbroich (2009), Harnessing Value for Transportation Investment, June, Technical Report CTS09-18PS, University of Minnesota (http://www.cts.umn.edu/Research/Featured/ValueCapture/).

Lepak, D., K. Smith and M. Taylor (2007), 'Value Creation and Value Capture: A Multilevel Perspective', Academy of Management Review, Vol. 32, No. 1, pp. 180-94.

Levinson, D. and E. Istrate (2011), Access for Value: Financing Transportation through Land Value Capture (Washington, DC: Brookings Institution).

Martínez, L. and J. Viegas (2012), 'The Value Capture Potential of the Lisbon Subway', The Journal of Transportation and Land Use, Vol. 5, No. 1, pp. 65-82.

McIntosh, J. (2011), Alternative Funding Mechanisms for Public Transport in Perth: the Potential Role of Value Capture (Perth: Curtin University Sustainability Policy Institute). Medda, F. and M. Modelewska (2011), Land Value Capture as a Funding Source for Urban Investment: The Warsaw Metro System (Warsaw: Ernst \& Young, Warsaw).

Meerman, J. (1980), ‘Are Public Goods Public Goods?’, Public Choice, Vol. 35, No. 1, pp 4557.

Mitchell, J. (2008), Business Improvement Districts and the Shape of American Cities (Albany: State University of New York Press). 
Naccarato, R. (2007), ‘Tax Increment Financing: Opportunities and Concerns’, Tennessee Advisory Commission on Intergovernmental Relations, Staff Research Brief 14, pp. 111.

National Audit Office (2010), 'HM Treasury: Financing PFI Projects in the Credit Crisis and the Treasury’s Response', HC 287, Parliamentary Session 2010-2011 (London: The Stationery Office).

Office for Budget Responsibility (OBR) (2013), Fiscal Sustainability Report (Norwich: The Stationery Office).

Pollock, A. and D. Price (2008), 'Has the NAO Audited Risk Transfer in Operational Private Finance Initiative Schemes?’, Public Money \& Management, Vol. 28, No. 3, pp. 173-78.

Portland City Council (2009), Portland Streetcar System Concept Plan: A Framework for

Future corridor Planning and Alternatives Analysis (Portland, Oregon: City of Portland Bureau of Transportation).

Portland Streetcar Inc. (2008), Portland Streetcar Development Oriented Transit (Portland, Oregon: The Office of Transportation and Portland Streetcar, Inc.).

Quesnay, F. (1963), 'General Maxims for the Economic Government of an Agricultural Kingdom', in R. Meek (ed.), The Economics of Physiocracy: Essays and Translations (Cambridge, MA: Harvard University Press), pp. 231-62. (Original work published 1767) Sandford, M. (2013), 'Business Improvement Districts’, SN/PC/04591 (London: Parliament \& Constitution Centre).

Saxer, S. (2000), 'Planning Gain, Exactions, and Impact Fees: A Comparative Study of Planning Law in England, Wales, and the United States', The Urban Lawyer, Vol. 32, No. 1, pp. 21-71.

Scottish Futures Trust (2011), Welcome (http://www.scottishfuturestrust.org.uk/).

Shaoul, J. (2005), 'A Critical Financial Analysis of the Private Finance Initiative: Selecting a Financing Method or Allocating Economic Wealth?', Critical Perspectives on Accounting, Vol. 16, No. 4, pp. 441-471.

Shaoul, J., A. Stafford, and P. Stapleton (2011), 'Private Finance: Bridging the Gap for the UK's Dartford and Skye Bridges?’, Public Money \& Management, Vol.31, No. 1, pp. 51-58.

Smith, J. and T. Gihring (2006) 'Financing Transit Systems through Value Capture: An Annotated Bibliography', American Journal of Economics and Sociology, Vol. 65, No. 3, pp. 751-86.

Transport for London (2012), Proposed Extension of the Northern Line to Nine Elms and Battersea: Update (http://www.tfl.gov.uk/assets/downloads/corporate/nle-leaflet.pdf). 
Ward, K. (2012), Tax Increment Financing - Continuing to Learn from Chicago (http://www.nlgn.org.uk/public/2012/tax-increment-financing-continuing-to-learn-fromchicago/).

Yin, R. (2003), Case Study Research: Design and Methods (Thousand Oaks, CA: Sage). 